\title{
REDACTIONEEL
}

\section{Hedendaagse jeugdcriminaliteit: nieuwe vragen en enkele antwoorden na een historische daling}

\author{
André van der Laan, Stefaan Pleysier \& Frank Weerman
}

In het Tijdschrift voor Criminologie wordt regelmatig aandacht besteed aan jeugdcriminaliteit. Uit een cijfermatig overzicht dat werd opgemaakt in het kader van 50 jaar TvC (Rovers \& Boers, 2009) komt naar voren dat de term 'jeugdcriminaliteit' zelfs afgetekend op nummer 1 staat in de top 15 van meest toegekende trefwoorden in de geschiedenis van het tijdschrift. In 1995, inmiddels alweer 25 jaar geleden, verscheen ook een themanummer over dit onderwerp, getiteld 'Zin en onzin over jeugdcriminaliteit'. In de inleiding van dat nummer constateerde de redactie dat zich in de beeldvorming over jeugdcriminaliteit enkele belangrijke veranderingen hadden voorgedaan. Waar eerder vooral nadruk lag op relatief onschuldige delicten, voornamelijk gepleegd door jongens tijdens het opgroeien, leken de berichtgeving en discussie over jeugdcriminaliteit verontruster te worden. Media en politiek spraken in toenemende mate over een kleine groep jongeren, 'de harde kern' genaamd, die op steeds jongere leeftijd steeds ernstiger delicten pleegden en gewelddadiger zouden zijn. Met het themanummer wilde de toenmalige redactie de nieuwe veronderstellingen tegen het wetenschappelijke licht houden. De bijdragen van dit themanummer geven vervolgens een genuanceerd beeld van deze ontwikkelingen, aan de hand van verschillende databronnen en invalshoeken, inclusief politiecijfers en zelfrapportageonderzoek.

In 2007, ondertussen alweer dertien jaar geleden, schreven Bruinsma en Weerman in $\mathrm{TvC}$ de bijdrage 'Vernieuwingen in de verklarende jeugdcriminologie' (Bruinsma \& Weerman, 2007). In dit artikel werd een drietal thema's besproken waarin zich toen recent nieuwe ontwikkelingen hadden voorgedaan: (1) de ontwikkeling en latere levensloop van daders, (2) de invloed van vrienden op het criminele gedrag van jongeren, en (3) de impact van de gelegenheid in de geografische of ruimtelijke context op criminaliteit. Deze drie thema's zouden zichzelf, aldus de auteurs, opnieuw hebben uitgevonden in pakweg het decennium voorafgaand aan hun bijdrage. Recent onderzoek op dit terrein zou hebben gezorgd voor 'nieuwe antwoorden op oude vragen'.

Meer dan een decennium later is het domein van de jeugdcriminologie nog steeds in verandering. Er hebben zich belangrijke ontwikkelingen in omvang en aard van de jeugdcriminaliteit voorgedaan die schreeuwen om verklaring en nader onderzoek. Mede door de opkomst van internet en sociale media ontwikkelden zich nieuwe fenomenen en delictsvormen en is de sociale context van klassieke vormen van delinquent gedrag veranderd. Hoog tijd voor dit tijdschrift om opnieuw de balans op te maken. In dit dubbele themanummer gaan we opnieuw op zoek naar 'nieuwe antwoorden op oude vragen', maar gaan we ook op zoek naar nieuwe 
thema's en uitdagingen, en exploreren we eerste antwoorden op deze nieuwe vragen.

\section{De daling in jeugdcriminaliteit sinds 2007}

Misschien wel het meest in het oog springende fenomeen sedert de publicatie van Bruinsma en Weermans artikel is de daling van de (geregistreerde) jeugdcriminaliteit (figuur 1). Sinds het midden van de vorige eeuw was de geregistreerde jeugdcriminaliteit (de bij de politie bekende jeugdige verdachten van een misdrijf) gestegen, met een piek rond het midden van de jaren 1990 (rond het verschijnen van het vorige themanummer) en na een tijdelijke lichte daling weer een gestaag stijgende trend. Het artikel van Bruinsma en Weerman verscheen in 2007 op het moment dat de geregistreerde jeugdcriminaliteit hoog was. In het decennium daarna daalde het aantal jongeren dat verdacht wordt van criminaliteit echter aanzienlijk (Van der Laan \& Weijters, 2015). Dat is in Nederland zo, maar met enige variatie en foutenmarges geldt deze observatie voor nagenoeg de hele westerse wereld, of althans de landen waar cijfers met betrekking tot jeugddelinquentie beschikbaar zijn (zie o.a. Berghuis \& De Waard, 2017; Van der Laan \& Beerthuizen, 2018). Bovendien corresponderen deze trends in de geregistreerde jeugdcriminaliteit met die van de algemene criminaliteit, al zette de daling daar nog eerder in (zie o.a. Van Dijk e.a., 2012; Farrell e.a., 2011). En tot slot is de daling, zowel bij jeugdigen als bij volwassenen, niet alleen zichtbaar in de geregistreerde cijfers van politie en justitie, maar ook (hoewel in minder uitgesproken mate) in slachtofferenquêtes en zelfrapportagestudies (Van der Laan e.a., 2017).

Er zijn ondertussen verschillende verklaringen voor die geobserveerde daling in de criminaliteit geopperd. Misschien wel de meest geciteerde verklaring is de zogenoemde 'beveiligingshypothese' (Farrell e.a., 2011; 2014; Van Dijk e.a., 2012). Door de toegenomen 'securisering' in onze samenleving, en allerhande beveiligingsmaatregelen zoals alarminstallaties in auto's, betere inbraakbeveiliging van woningen en cameratoezicht in het openbare domein of tags en poortjes in winkels, komen potentiële daders minder in de gelegenheid om delicten te plegen. Volgens Farrell en collega's hebben deze maatregelen een groot effect, vooral op 'debut crimes', de delicten waarmee een criminele carrière doorgaans wordt gestart, meestal op jonge leeftijd (denk aan winkeldiefstal, inbraak of geweld op straat). De toegenomen aanwezigheid van beveiligingsmaatregelen weerhoudt deze jongeren van het plegen van dergelijke 'instapdelicten', en verkleint bijgevolg ook de kans op het ontwikkelen van een criminele carrière.

Andere onderzoekers verwijzen voor de daling van de jeugdcriminaliteit naar de veranderende maatschappelijke houding ten opzichte van risicogedrag (Van der Laan e.a., 2018). Criminaliteit, en dus ook jeugdcriminaliteit, is vaak het gevolg van de blootstelling aan of accumulatie van risicofactoren, en een tekort aan of het ontbreken van beschermende of protectieve factoren. Jongeren zijn, omwille van een aantal maatschappelijke veranderingen, in het afgelopen decennium aan minder risicofactoren blootgesteld, terwijl het aantal beschermende factoren 


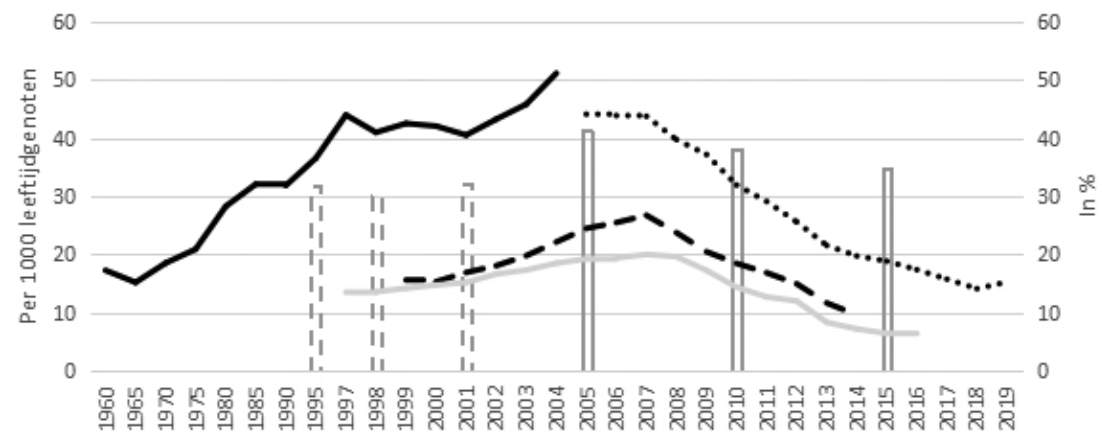

\footnotetext{
$\square$ Zelfgerapporteerde daders (\%) ${ }^{*}$

- Bij politie bekende (gehoorde) verdachten (per 1000)**

*... Geregistreerde verdachten (per 1.000)***

- Aangehouden verdachten (per 1.000)

-Strafrechtelijke daders (per 1.000)
}

*1995-2001: autochtoon Nederlandse jongeren; 2005-2015: random steekproeven alle Nederlandse jongeren.

** 1960-2004: gehoorde verdachten, Politiestatistiek.

*** 2005-2019: geregistreerde verdachten, BVH.

Bronnen:

Zelfgerapporteerde daders, jaren 1995, 1998 en 2001: WODC zelfgerapporteerde jeugdcriminaliteit (Van der Laan e.a., 1998; Kruissink \& Essers, 2004); jaren 2005, 2010 en 2015: WODC Monitor Zelfgerapporteerde Jeugdcriminaliteit (MZJ; Van der Laan \& Beerthuizen, 2016).

Verdachten: bekende/gehoorde verdachten Politiestatistiek reeks gestopt in 2005 (CBS, 2020a); geregistreerde verdachten BVH: CBS/SSB-reeks gestart in 2005 (CBS, 2020b); aangehouden verdachten HKS: CBS/SSB-reeks gestopt in 2015 (CBS, 2020b).

Strafrechtelijke daders: OBJD/WODC (Van der Laan \& Beerthuizen, 2018).

\section{Figuur 1 Ontwikkelingen in de jeugdcriminaliteit (12- tot 18-jarigen), 1960-2020}

vanuit het gezin toeneemt. Op basis van drie opeenvolgende cohorten van de Monitor Zelfgerapporteerde Jeugdcriminaliteit (MZJ 2005, 2010 en 2015) kan inderdaad worden vastgesteld dat dergelijke veranderingen in risico- en beschermende factoren zich hebben voorgedaan bij 12- tot 18-jarigen (Van der Laan e.a., 2018). Jongeren uit het meest recente cohort zeggen, in vergelijking met oudere jongeren, minder te worden blootgesteld aan risicofactoren voor jeugddelinquentie, zoals alcoholgebruik en delinquente vrienden, en rapporteren ook meer beschermende opvoedingsfactoren, zoals ervaren emotionele steun, betrokkenheid en monitoring door ouders.

Als verklaring wordt ook vaak gewezen op de toegenomen digitalisering van de samenleving en de belangrijke rol die de opkomst van sociale media en de smartphone daarbij heeft gespeeld (Berghuis \& De Waard, 2017; Van der Laan e.a., 2017; Weerman, 2017). Deze ontwikkelingen hebben geleid tot grote verschuivin- 
gen in de tijdbesteding van jongeren. Jongeren spenderen, in vergelijking met een tiental jaar geleden, minder tijd met vrienden op straat en in de publieke ruimte, en meer tijd achter een beeldscherm en online op sociale media (Wennekers e.a., 2016; Kanne e.a., 2019). Dit is een niet te miskennen ontwikkeling, want hoe vrije tijd wordt ingevuld door jongeren kan een belangrijke risico- of beschermende factor zijn bij jeugdcriminaliteit. Met name de hoeveelheid tijd die ongestructureerd wordt doorgebracht met leeftijdgenoten in de publieke ruimte ('rondhangen') is gerelateerd aan een verhoogde kans op het plegen van delicten (zie o.a. Hoeben, 2016; Osgood \& Anderson, 2004). De hypothese is dan dat de afname van het ongestructureerd rondhangen in het vrijetijdspatroon van jongeren mede een verklaring biedt voor de recente daling van de jeugdcriminaliteit. Deze verklaring lijkt te worden ondersteund door een recent gepresenteerde studie onder Zweedse jongeren (Svensson \& Oberwittler, 2019). Uit verschillende waves van een surveyonderzoek blijkt dat het vrijetijdspatroon van jongeren met name sinds 2008 (maar ook al daarvoor) sterk is veranderd. Jongeren brengen opmerkelijk minder vaak tijd door met ongestructureerde activiteiten, zijn minder avonden bij hun vrienden en raken minder vaak dronken. Deze veranderingen in het vrijetijdspatroon lijken in dit onderzoek relatief het meest bij te dragen aan de daling in jeugdcriminaliteit, in vergelijking met andere factoren, zoals een verbeterde band met ouders en school en strengere morele opvattingen.

\section{Waarom toch een themanummer? Recente ontwikkelingen met betrekking tot jeugdcriminaliteit}

Maar indien zowel de geregistreerde als de (zelf)gerapporteerde jeugdcriminaliteit zo sterk is gedaald - Berghuis en De Waard (2017) spreken zelfs over 'verdampende jeugdcriminaliteit' -, is een themanummer over hedendaagse jeugdcriminaliteit dan wel aan de orde? Om meerdere redenen denken wij dat dit wel het geval is. Niet alleen is jeugdcriminaliteit nog steeds een belangrijk en onder sommige groepen jonge daders hardnekkig probleem, de aard en context van de jeugdcriminaliteit zijn sinds het vorige themanummer en het eerdergenoemde artikel over de verklarende jeugdcriminologie ook sterk veranderd.

Om te beginnen is het uiteraard niet zo dat een gedaalde jeugdcriminaliteit, zowel in Nederland als in België, een reden kan zijn om het onderzoek, de kennis en de knowhow met betrekking tot dit fenomeen af te bouwen. Daarvoor is niet alleen het absolute aantal jongeren dat omwille van gepleegde feiten in aanraking komt met politie en justitie te groot (in 2019 werden in Nederland ruim 18.000 minderjarigen en 36.000 jongvolwassenen als verdachte door de politie geregistreerd (CBS, 2020b)), ook de slachtoffers van jeugdcriminaliteit verdienen het dat de problematiek ernstig wordt genomen. Bovendien zien we, ongeacht de hiervoor beschreven (dalende) trend in de criminaliteit gepleegd door jeugdige en jongvolwassen daders, dat de klassieke age-crime curve overeind blijft (zie o.a. Moffitt, 2018). Dit wil zeggen dat criminaliteit, maar ook het zogenoemde antisociale gedrag, nog steeds gepleegd wordt door jongeren en jongvolwassenen, met een piek pakweg tussen 16 en 21 jaar. Jongeren zijn nu eenmaal 'oververtegen- 
woordigd' als het gaat om het vertonen van risicogedrag, zoals overmatig drankof drugsgebruik en riskant rijgedrag, maar dus ook bij antisociaal gedrag, overlast en criminaliteit.

Ten tweede weten we ondertussen dat de ontwikkelingen in de jeugdcriminaliteit minder uniform en algemeen zijn dan oorspronkelijk werd gedacht. De jeugdcriminaliteit daalt, maar niet noodzakelijk overal en op dezelfde wijze bij elke groep. Er zijn grote verschillen wanneer deze algemene trend wordt opgesplitst en bekeken naar aard van de criminaliteit of de (geografische) plaats van plegen (zie o.a. Van der Laan \& Beerthuizen, 2018; McVie e.a., 2020; Sleutjes \& Beerthuizen, 2018). In zelfrapportagestudies zien we weliswaar een afname in het aantal delinquente jongeren, maar tegelijkertijd blijkt dat de groep ernstige delinquente daders tussen 2005 en 2015 stabiel is en niet in omvang is afgenomen. Voorts blijkt dat de recidive onder jeugdigen die al eens eerder met het $\mathrm{OM}$ in aanraking zijn gekomen sinds 2013 niet is afgenomen, maar zelfs licht stijgt in de jaren 2011-2016 (Weijters e.a., 2019). De problemen lijken met name groot bij de jongeren die worden bestempeld als jeugdige veelplegers (Weijers e.a., 2010) of worden gerekend tot de 'top zoveel' van wetsovertreders die in verschillende gemeenten worden bijgehouden (zie bijv. Van Grinsven \& Verwest, 2017). Daarnaast zijn er buurten waar de jeugdcriminaliteit ernstiger is dan elders en waar ook niet of minder sterk sprake is van een afname (Sleutjes \& Beerthuizen, 2018). Kortom, binnen het totaalplaatje van de dalende jeugdcriminaliteit zijn er groepen en gebieden aan te wijzen waar de problemen hardnekkiger lijken te zijn en die niet of nauwelijks lijken te profiteren van alle gunstige ontwikkelingen van de afgelopen jaren. Anders gezegd: niet alleen de spreiding, maar ook de ontwikkelingen in jeugdcriminaliteit zijn ongelijk verdeeld in de samenleving. Onderzoek naar de kenmerken en achtergronden hiervan is van het grootste belang om ook hier een effectief beleid te kunnen voeren.

Een derde reden voor een nieuw themanummer is dat in Nederland in de recente politiecijfers van 2019 en 2020, in vergelijking met 2018, een lichte toename in de jeugdcriminaliteit te zien valt (CBS, 2020b; Politie.nl, 2020), waaronder een toename van betrokkenheid van jongeren bij steekincidenten in de afgelopen twee jaar (Politie.nl, 2020). Ook in België liet de instroom van minderjarige delictplegers bij de jeugdparketten eerder al, in 2016, een kleine opwaartse knik zien, om daarna in 2017 en 2018 opnieuw licht te dalen (OM, 2019). Uiteraard kan hier sprake zijn van bepaalde registratie-effecten, of van kleine, 'toevallige' schommelingen, maar het is ook mogelijk dat deze ontwikkelingen de weerslag vormen van een aantal nieuwe fenomenen met betrekking tot jeugdcriminaliteit en dat de cijfers wijzen op het eind van de daling in jeugdcriminaliteit. Het is niet ondenkbaar dat, na een periode van dalende criminaliteit, de aandacht van burger en overheid is 'verslapt', waardoor de gelegenheid tot het plegen opnieuw kan stijgen. De eerder vernoemde 'beveiligingshypothese', als verklaring voor de daling van de (jeugd)criminaliteit, suggereert dat de evolutie van de criminaliteit een dergelijke cyclische beweging volgt (Van Dijk e.a., 2012). Met andere woorden, het is raadzaam om nog steeds de vinger aan de pols te houden en deze en toekomstige statistieken grondig te bestuderen. Voor criminologen is het zaak om 
ook nu weer verklaringen te ontwikkelen en onderzoeken voor eventuele stijgingen of fluctuaties in het niveau van jeugdcriminaliteit.

Ten vierde heeft zich sinds het vorige themanummer een heel domein van jeugdcriminaliteit verder ontwikkeld waarvoor criminologen 25 jaar geleden nog nauwelijks aandacht hadden: online vormen van delinquent gedrag. Daarbij gaat het om zowel gedigitaliseerde criminaliteit, zoals bedreiging of fraude via sociale media en bepaalde apps, als om meer of minder geavanceerde vormen van cybercriminaliteit - ddos-aanvallen, hacken, ransomware en dergelijke. Uit zelfrapportageonderzoek onder jongeren blijkt dat de betrokkenheid bij online delinquentie tegenwoordig bijna net zo gewoon is als het plegen van traditionele vormen van offline jeugdcriminaliteit, al gaat het meestal om relatief onschuldige vormen, zoals inloggen zonder iemands toestemming (zie Van der Laan \& Beerthuizen, 2016). Sommigen opperen daarom dat de hiervoor beschreven daling van de geregistreerde (jeugd)criminaliteit kan wijzen op een verschuiving van 'klassieke' offline criminaliteit naar de digitale wereld (Van der Laan e.a., 2017; Weerman, 2017). Dat zou gezien de toegenomen digitalisering van de samenleving en daarmee gepaard gaande veranderende vrijetijdspatronen van jongeren niet onlogisch zijn. Deze online vormen van jeugdcriminaliteit lijken grotendeels onder de radar te blijven van de politie, gezien het geringe aantal verdenkingen en vervolgingen onder jongeren voor online delicten in vergelijking met de zelfrapportagegegevens (Van der Laan e.a., 2016). Of en in welke mate er nu echt sprake is van een dergelijke verschuiving is echter vooralsnog onduidelijk. Ook is het nog maar de vraag of er eerder sprake is van een verplaatsing, in de zin dat jongeren met een bepaald risicoprofiel eerst offline delicten pleegden en nu (ook) zijn overgegaan tot online delicten, of van een nieuwe groep daders, met een geheel eigen profiel (Rokven e.a., 2017).

Ten vijfde is er de afgelopen jaren met betrekking tot jeugdcriminaliteit in de media toegenomen aandacht voor een aantal specifieke fenomenen en delictsoorten. Zo is er al langere tijd bezorgdheid over jongeren die betrokken zijn bij drugshandel en 'ondermijnende criminaliteit' (onder meer aangezwengeld door een artikel van Tops en Tromp, 2017). Daarnaast was er eind 2019 en begin 2020 veel berichtgeving over mes- en steekincidenten en de daardoor veronderstelde toegenomen betrokkenheid van jongeren daarbij in verschillende steden van Nederland. Als inspiratiebron lijken hierbij gelijkaardige feiten van 'knife crime' in het Verenigd Koninkrijk te dienen, waarvan op internet en sociale media verschillende voorbeelden circuleren. Er was veel aandacht in de media voor 'drillrap', een agressieve muziekvorm waarbij jongeren op internet poseren met hoodies en gezichtsbedekkingen, straattaal en symboliek gebruiken en allerhande wapens en buit laten zien, waaronder machetes en andere zelfgefabriceerde messen ('shanks'). Drillrap is komen overwaaien uit de Verenigde Staten en later het Verenigd Koninkrijk, en biedt voor jongeren een manier om hun straatidentiteit te uiten en het harde leven in achterstandsbuurten te beschrijven en uit te vergroten (Roks, 2020). Deze muzieksoort wordt door de media soms een-op-een gelinkt aan jeugdcriminaliteit en geweld, mede naar aanleiding van enkele gevallen van messengeweld waarbij daders en slachtoffers zich bezighielden met drillrap. In hoeverre dit te generaliseren valt naar alle drillrap en muzikanten die 
zich daarmee bezighouden, is nog de vraag, en onduidelijk is vaak wat 'pose' is en wat echt (zie onder meer Ilan, 2020).

Deze nieuwe fenomenen illustreren een zesde reden waarom hernieuwde aandacht voor jeugdcriminaliteit belangrijk is: een ingrijpend veranderde sociale context van jeugdcriminaliteit. Sinds de opkomst van sociale media en het dagelijkse gebruik daarvan via smartphones zijn de online contacten en communicatiepatronen van jongeren steeds meer relevant geworden als sociale context voor gedrag, en dat omvat ook jeugdcriminaliteit. Zo zijn problematische jeugdgroepen en 'gangs' zich steeds meer online gaan manifesteren, en tegenwoordig spelen veel jongeren online met een 'gangsta'-imago, hoewel ze niet per se deel uitmaken van een groep (zie bijv. Van Hellemont, 2012; Storrod \& Densley, 2017; Van den Broek, 2013). En conflicten en provocaties op sociale media leiden regelmatig tot geweld onder jongeren in de offlinewereld, met ernstige of zelfs fatale gevolgen (zie bijvoorbeeld overzichten van Irwin-Rogers \& Pinkney, 2017; Patton e.a., 2014). Welke invloed deze nieuwe online context heeft op jeugdcriminaliteit, niet alleen in de online-, maar ook in de offlinewereld, en welke processen hierbij een rol spelen, is nog grotendeels een braakliggend terrein voor criminologen (zie eerder hierover Weerman, 2019).

Kortom: niet alleen is jeugdcriminaliteit nog steeds een belangrijk en onder sommige groepen jonge daders hardnekkig probleem, de aard en context van de jeugdcriminaliteit zijn sinds het vorige themanummer en het eerdergenoemde artikel over de verklarende jeugdcriminologie eveneens sterk veranderd en dat verdient opnieuw aandacht.

\section{In dit themanummer}

De artikelen die zijn opgenomen in dit themanummer bieden een staalkaart van hedendaags criminologisch onderzoek naar jeugdcriminaliteit, waarbij een aantal van de hiervoor genoemde thema's herkenbaar is.

We beginnen met een verkenning van het relatief nieuwe domein van onderzoek dat zich sinds het vorige themanummer over jeugdcriminaliteit heeft ontwikkeld: online jeugdcriminaliteit. Op basis van twee grootschalige vragenlijstonderzoeken biedt Ena Coenen in de bijdrage 'Een eerste blik op online delinquentie' relevante eerste inzichten in de omvang van online delinquentie onder jongeren in Vlaanderen, wat betreft zowel dader- als slachtofferschap. Daarnaast worden de risicoprofielen in kaart gebracht voor daders, slachtoffers en jongeren die zowel dader als slachtoffer zijn van dit type jeugdcriminaliteit. De auteur constateert prevalenties tussen 10 en 20 procent voor de onderzochte vormen van online daderschap onder Vlaamse jongeren. Dat ligt lager dan blijkt uit eerdergenoemd zelfrapportageonderzoek onder Nederlandse jongeren. Mogelijk is dit te wijten aan methodische verschillen in het onderzoek (zoals minder vragen over online delicten), maar wellicht wijst het resultaat ook op verschillen tussen de landen. Verder signaleert Coenen interessante verschillen tussen risicofactoren van online en offline daderschap: sommige klassieke risicofactoren lijken niet of nauwelijks met online daderschap samen te hangen. 
In de bijdrage 'Online jeugdcriminaliteit en "verkeerde vrienden"' onderzoeken Yaloe van der Toolen, Marleen Weulen Kranenbarg en Frank Weerman de rol van delinquente vrienden bij jeugdcriminaliteit, met speciale aandacht voor online vormen van jeugdcriminaliteit. In een onderzoeksgroep bestaande uit scholieren uit het middelbaar onderwijs en mbo-studenten, met nadruk op informatica-interesses en informaticastudenten, is uitgebreid gemeten welke jongeren zich schuldig maken aan een brede verzameling van cyber- en gedigitaliseerde delicten. Daarbij gebruiken de auteurs een voor de Nederlandse criminologie vernieuwende methode om delinquent gedrag van vrienden te meten. De auteurs hanteren zowel de standaardmethode (wat zij aanduiden als indirecte bevraging, namelijk respondenten te vragen naar eventueel delinquent gedrag van vrienden) als een meer directe bevraging, door het sociale netwerk van jongeren in kaart te brengen, waarbij de vrienden zelf gevraagd kunnen worden over hun delinquente gedrag. De directe bevraging kon alleen worden gebruikt om het delinquente gedrag van schoolvrienden in kaart te brengen, maar Van der Toolen e.a. passen de indirecte bevraging ook toe op vrienden met wie jongeren buiten school omgaan, alsmede vrienden met wie jongeren alleen online contact hebben. Uit de analyses komt naar voren dat jongeren zelf veelal het delinquente gedrag van hun vrienden te laag inschatten als die scores worden vergeleken met die van vrienden zelf. Zeker waar het om cyberdelinquentie gaat, blijkt de inschatting moeilijk. Anders gezegd, de resultaten suggereren dat respondenten vaak een onvolledig of onjuist beeld hebben van het delinquente gedrag van hun vrienden.

Ook in de bijdrage 'Risicogedrag van jongeren. In hoeverre verschilt de invloed van leeftijdsgenoten op het beginnen met risicogedrag en aanpassen in risicogedrag?' van Aart Franken, Jan Kornelis Dijkstra, Zeena Harakeh en Wilma Vollebergh wordt ingegaan op de rol van vrienden bij gedrag van jongeren, in dit geval risicogedrag in brede zin, inclusief delinquentie, alcoholgebruik en roken. Vernieuwend aan dit artikel is dat niet alleen wordt gekeken naar de invloed van vrienden op zichzelf, maar dat onderscheid wordt gemaakt tussen het beginnen met risicogedrag en het veranderen daarvan. Er wordt gebruik gemaakt van de socialenetwerkmethode, die leidt tot een directe meting van gedrag van vrienden, maar anders dan in het voorgaande onderzoek konden de auteurs gebruik maken van geavanceerde netwerkmethoden om invloeds- en selectie-effecten te schatten. De data waren afkomstig van een longitudinaal onderzoek met drie meetmomenten bij jongeren vanaf het eerste jaar in het voortgezet onderwijs, waarbij niet alleen gegevens van jongeren zelf, maar tevens gegevens uit hun vriendennetwerk op school zijn verzameld. Het onderzoek is een gedegen voorbeeld van kwantitatief onderzoek naar de mechanismen die werken in de start en continuering van invloedsprocessen van vrienden. De resultaten suggereren dat de invloed van vrienden bij de aanvang van risicogedrag anders is dan bij het voortduren en weer wijzigen van gedrag. Dit is belangrijk voor de aanpak van jeugdcriminaliteit, omdat de rol van vrienden bij de start mogelijk minder belangrijk is dan gedacht.

De volgende twee artikelen gaan over een van de groepen hoogactieve en hardnekkige jonge daders die worden onderscheiden in media en beleid, namelijk de jonge veelplegers. In de bijdrage 'Wie zijn jeugdige veelplegers?' beantwoorden Frank Weerman, Gerben Bruinsma, Wim Bernasco en Lieven Pauwels twee 
methodologisch en inhoudelijk belangrijke vragen. Ten eerste de vraag in hoeverre er verschillen zijn in welke jongeren als veelpleger worden aangemerkt als dit gebaseerd wordt op politiecijfers of op basis van zelfrapportage, en ten tweede in hoeverre de achtergronden van veelplegers verschillen als je afgaat op beide methoden. In $\mathrm{TvC}$ is in het verleden al regelmatig methodologische discussie geweest over de relevantie van bijvoorbeeld zelfrapportage naast politieregistraties (Bruinsma, 1991; Swanborn, 1996; Van der Heijden e.a., 1995), waarin beide methoden bijna werden gezien als elkaar wederzijds uitsluitend. Recente studies tonen echter aan dat beide methoden elkaar goed kunnen aanvullen (zie bijv. Weijters e.a., 2016). Ook dit artikel over jeugdige veelplegers maakt dit duidelijk. Gebruik makend van een longitudinale steekproef van jeugdigen uit Den Haag en omgeving, het SPAN-project, koppelden de auteurs zelfrapportagegegevens aan politieregistraties. Uit de vergelijking tussen zelfrapportage en politiegegevens blijkt ten eerste dat veel delinquente jongeren in de woorden van de auteurs 'onder de radar blijven van politie en justitie'. Ten tweede vonden de auteurs dat veelplegers op basis van beide bronnen op min of meer dezelfde achtergrondkenmerken van elkaar te onderscheiden waren, met dit verschil dat politiebronnen suggereren dat veelplegers vaker rondhangen dan uit zelfrapportage blijkt. De politie heeft dus vooral de jongeren die veel rondhangen op straat in beeld. Dit zijn belangrijke bevindingen, omdat het duidelijk maakt dat politie en justitie slechts zicht hebben op een beperkt deel van de jeugdige daders en op een beperkt deel van de risicofactoren relevant voor delinquent gedrag. Veel beleid is gebaseerd op deze politie- en justitieregistraties, terwijl met dit onderzoek opnieuw duidelijk wordt dat die kennis slechts het topje van de ijsberg is. Evidence-based practice voor de aanpak van jeugdcriminaliteit moet zich dus baseren op informatie uit meerdere van elkaar onafhankelijke bronnen.

In de bijdrage 'Jonge veelplegers en hun worsteling om te stoppen met criminaliteit' gaat Ido Weijers in op het desistance-proces bij deze specifieke groep jonge daders. In een unieke langlopende longitudinale studie van door de politie aangemerkte veelplegers in Utrecht zijn registraties, dossiers en interviews gecodeerd en geanalyseerd. Om het proces van desistance te kunnen begrijpen, wordt gebruik gemaakt van diverse theoretische inzichten, zoals die van de 'age-graded' theorie van Sampson en Laub, de 'emerging adulthood'-theorie van Arnett en het vierfasemodel dat Prochaska en DiClemente hebben ontwikkeld voor het stoppen met drugsgebruik, aangevuld met recente bevindingen over neurologische ontwikkeling van de hersenen. Weijers clustert de groep veelplegers in vier stadia aan de hand van hun ontwikkeling en vorderingen in het desistance-proces: degenen die volharden in hun criminele leefstijl, degenen die erkennen dat er toch schaduwkanten zijn maar nog niet besluiten te stoppen, degenen die het stoppen voorbereiden en degenen die echt stoppen, hier consolideren genoemd. De studie maakt duidelijk dat het stoppen met crimineel gedrag na een carrière als jeugdige veelpleger een complex en langdurig proces is, waarin een centrale rol is weggelegd voor de motivatie van de veelpleger zelf. Opvallend in dit proces is vooral de centrale rol van binding met belangrijke anderen, zoals de partner of ouders, en het verbreken van bindingen met delinquente vrienden, terwijl de rol van politie, justitie of hulpverlening weinig wordt genoemd. Een andere conclusie is dat het 
stoppen met criminaliteit kan worden opgevat als een extreem late vorm van volwassen worden.

In de bijdrage 'Wie houdt de wacht? Veranderingen in toezicht tijdens de jongvolwassenheid' onderzoeken Jessica Hill en Arjan Blokland welke veranderingen zich voordoen met betrekking tot delinquent gedrag in de jongvolwassenheid en in hoeverre de rol van toezicht op het gedrag verandert tijdens deze levensfase. In de kinder- en tienertijd zijn vooral ouders relevant. Maar is dat nu ook zo bij jongvolwassenen? En welke vorm krijgt de invloed van ouders en andere toezichthouders op het gedrag van jongvolwassenen? Zich baserend op een longitudinale studie onder jongvolwassenen signaleren de auteurs dat ouderlijke controle nog steeds een beschermende (of protectieve) rol speelt bij delinquent gedrag en dat er geen aanwijzingen zijn dat toezicht van anderen relevanter wordt en de rol van ouders al overneemt. Mogelijk heeft het ontbreken van een toezichthoudende rol van anderen, zoals een partner, te maken met de relatief hogere leeftijd waarop jongvolwassenen een vaste romantische levenspartner krijgen. Dat sluit aan bij het idee van een nieuwe speciale levensfase, de 'emerging adulthood', in het Nederlands ontluikende volwassenheid genoemd, die zich kenmerkt door zowel onafhankelijkheid als een tijdelijke vrijblijvendheid in de ontwikkeling naar de volwassenheid toe. De resultaten van het onderzoek lijken erop te wijzen dat in deze fase de eigen (zelf)controle op gedrag steeds prominenter wordt.

De laatste twee bijdragen van dit themanummer hebben betrekking op nieuwe inzichten met betrekking tot de reactie op en aanpak van jeugdcriminaliteit.

In de bijdrage 'Delinquentie, vrienden en "boosheid met liefde"' wordt een onderzoek beschreven van Adriaan Denkers en Jan Dirk de Jong naar de relatie tussen de bejegening door mentoren en het delinquente gedrag van hun leerlingen. De auteurs signaleren dat het niet alleen van belang is om te onderzoeken 'what works' bij delinquent gedrag van jongeren, maar dat er ook aandacht moet zijn voor 'who works'. De gedachte is dat een strenge maar liefdevolle bejegening kan bijdragen aan minder delinquent gedrag van jongeren, met name wanneer zij delinquente vrienden hebben. Hiermee hopen ze inzichtelijk te krijgen welke stijl van bejegenen relevant kan zijn in de aanpak van jeugdcriminaliteit. Tevens wordt in het artikel een interessante nieuwe en beknopte wijze van het meten van delinquent gedrag geïntroduceerd die specifiek is afgestemd op jongeren in een relatief moeilijke doelgroep van laaggeletterde en vaak licht verstandelijk beperkte jongeren. Het gaat om het gebruik van afbeeldingen van onder meer gedrag als ondersteuning van het stellen van vragen. Uit het onderzoek komt naar voren dat zowel duidelijkheid ('boosheid') als een vriendelijke bejegening ('liefde') door begeleiders samenhangt met minder delinquentie, en dat dit sterker het geval is voor jongeren met delinquente vrienden, hoewel dat niet geldt voor de interactieterm van beide eigenschappen. Het onderzoek is een eerste verkenning van zowel het concept als de manier van meten en toekomstig onderzoek zal moeten uitwijzen wat de uiteindelijke waarde is.

In de bijdrage 'Welzijn, primaire levensbehoeften en delinquentie bij adolescenten' gaan Colinda Serie, Stefaan Pleysier, Johan Put en Corine de Ruiter in op de vraag in hoeverre een verbeterd niveau van welzijn en primaire levensbehoeften, begrippen uit het zogenaamde 'Good Lives Model' (GLM) van Ward, kan bij- 
dragen aan vermindering van jeugdcriminaliteit. In Nederland is het dominante model in de aanpak van jeugdige delinquenten om recidive te voorkomen het Risk-Need-Responsivity (RNR)-model van Andrews en Bonta. Een veelgehoord commentaar op dit model is dat het zich veel richt op risico's en weinig rekening houdt met de mogelijkheden en krachten die jeugdige delinquenten zelf in huis hebben om hun primaire levensbehoeften te vervullen. In dit artikel gebruiken de auteurs daarom het GLM, een rehabilitatie-/resocialisatiemodel, waarin gesteld wordt dat het kunnen vervullen van primaire levensbehoeften van belang is voor recidivereductie. De verwachting is dat delinquentie samengaat met minder ervaren welzijn, omdat de levensbehoeften minder goed vervuld zouden worden. De aanpak van delinquentie zou dan ook sterk gericht moeten zijn op deze behoeften en de mogelijkheden die mensen hebben om die te vervullen. Het GLM is tot nu vooral bij ernstige delinquenten onderzocht (zie bijv. Barendregt, 2015), maar de auteurs gaan in dit artikel een stap verder en toetsen enkele centrale assumpties van GLM onder een steekproef uit de algemene populatie van jongeren in Vlaanderen. Ze vinden dat dit model ook toepasbaar is onder de door hen onderzochte jongeren. Dit laat zien dat naast de focus op risicofactoren vanuit het RNR-model ook inzichten over resocialisatie en rehabilitatie nodig zijn in de aanpak van criminaliteit bij jeugdigen.

\section{Tot slot}

Met dit themanummer wilde de redactie een staalkaart bieden van onderzoek naar hedendaagse jeugdcriminaliteit. De bijdragen in dit dubbelnummer laten zien dat het Nederlandse en Vlaamse onderzoek zowel explorerend als hypothesetoetsend van aard is, waarbij regelmatig gebruik wordt gemaakt van grootschalige longitudinale datasets. Waar in het vorige themanummer in 1995 al gerapporteerd werd over een aantal grootschalige longitudinale onderzoeken in Nederland, kunnen we constateren dat sindsdien het onderzoek naar jeugdcriminaliteit verder is geprofessionaliseerd en gekwantificeerd. In buiten- en binnenland zijn vele grootschalige langlopende surveyonderzoeken naar jeugdcriminaliteit. In de Verenigde Staten leidde dit tot tientallen publicaties met rijke datasets van studies en in Europa ook tot een internationaal vergelijkend initiatief als de International Self-Report and Delinquency survey (ISRD). Ook in Nederland en Vlaanderen zijn meerdere langlopende studies opgezet met als doel het toetsen van criminologische theorieën ter verklaring van jeugdcriminaliteit, waarvan in dit nummer enkele voorbeelden worden gegeven. Heden ten dage beperkt de jeugdcriminologie als 'discipline' zich niet alleen - voor zover dat ooit zo zou zijn geweest - tot enkel de (etiologische) studie van 'wie' criminaliteit pleegt en 'waarom' hij of zij dat doet. Onderzoekers bestuderen ook de vraag wat we kunnen doen om te voorkomen dat jongeren feiten plegen, of opnieuw feiten plegen indien ze eerder in de fout zijn gegaan. Een aanzienlijk deel van dit onderzoek is gebaseerd op de kennis van de eerder vernoemde risico- en protectieve factoren en veronderstelt dat het ombuigen van de risicofactoren of het versterken van de protectieve factoren leidt tot een adequate aanpak van jeugdcriminaliteit en reci- 
diverende jongeren (zie o.a. Farrington \& Welsh, 2007). Een ander deel van het onderzoek sluit aan bij het 'what works'-onderzoek naar bewezen effectieve interventies en programma's (Andrews e.a., 1990; Lipsey \& Cullen, 2007). En weer een ander deel van het onderzoek heeft zich gaandeweg meer toegelegd op de maatschappelijke context van jeugdcriminaliteit en processen van criminalisering (Pleysier e.a., 2012, 327). Het onderzoek in dit themanummer is overwegend kwantitatief van aard en kwalitatief onderzoek is beperkt tot één artikel. Dit is een meer algemeen beeld in $\mathrm{TvC}$, terwijl dergelijk onderzoek juist hele relevante inzichten in processen en mechanismen bij jeugdcriminaliteit kan opleveren, die kwantitatieve patronen kunnen verklaren of daar diepgang aan kunnen geven.

De jeugdcriminaliteit heeft in de afgelopen tien jaren een historische daling laten zien, in Nederland en in omringende landen, hoewel er in de meest recente jaren een lichte stijging lijkt te zijn afgaand op politiecijfers. Net als de spreiding van criminaliteit zelf is de daling ongelijk verdeeld. Bij sommige groepen en in sommige buurten blijft jeugdcriminaliteit een belangrijk probleem. Jeugdigen in de leeftijdsgroep van 12 tot ongeveer 23/25 jaar zijn in vergelijking met andere leeftijdsgroepen nog steeds oververtegenwoordigd in de criminaliteit. Zoals eerder al gezegd, alleen dit zijn al belangrijke redenen om de kennis over jeugdcriminaliteit actueel te houden. Met dit themanummer is vernieuwende kennis geleverd over jeugdcriminaliteit in Nederland en België, verklaringen en methoden en inzichten voor de aanpak van jeugdcriminaliteit. Op oude vragen zijn nieuwe antwoorden gegeven en nieuwe vragen zijn aan de orde gekomen.

Uiteraard blijven er nog vragen liggen. Hedendaagse maatschappelijke ontwikkelingen, zoals digitalisering en de daarmee gepaard gaande veranderende invulling van (vrije)tijdsbesteding, of aandacht voor fenomenen als ondermijning roepen nieuwe vragen op over de betrokkenheid van jongeren bij cyber- en gedigitaliseerde criminaliteit of activiteiten als drugshandel of ernstige gewelddadige criminaliteit. Daarnaast zijn er vragen over mogelijke nieuwe ontwikkelingen in de jeugdcriminaliteit. Recent worden in het maatschappelijke debat (opnieuw) zorgen geuit over verharding van criminaliteit onder jongeren, of het toenemend messenbezit en -gebruik onder scholieren. Dit zijn op zich geen nieuwe verschijnselen, maar nader onderzoek is wel geboden naar de vraag of de toename zo alarmerend is als in de media geopperd, onder welke groepen zij plaatsvindt, en wat de achtergronden daarvan zijn. En natuurlijk is ook nog veel onbekend over de gevolgen van de Coronacrisis en de genomen maatregelen voor de jeugdcriminaliteit. In eerste instantie leek de (jeugd)criminaliteit een extra duw naar beneden te krijgen ten tijde van de 'intelligente lockdown' en de daarbij behorende gelegenheidsbeperkingen. In de media lazen we echter ook dat niet iedereen zich aan de noodverordeningen kon houden, dit betrof onder meer jongeren zowel in grootstedelijk gebied als elders in het land. Politiecijfers van begin juli lieten een toename zien van het aantal registraties (en boetes) betreffende jeugdoverlast zoals samenscholing (zie data.politie.nl). Verder lijken de maatregelen ook gevolgen te hebben gehad voor online criminaliteit en waren er indicaties dat sommige risicofactoren voor jeugdcriminaliteit toenamen, zoals geldnood onder jongeren en toegenomen spanningen in de buurt. Wat de gevolgen hiervan zijn voor jeugdcrimi- 
naliteit op de langere termijn vraagt om nader onderzoek. Kortom, de bestudering van jeugdcriminaliteit is actueler dan ooit.

We wensen de lezer veel leesplezier.

\section{Literatuur}

Andrews, D., Bonta, J. \& Hoge, R. (1990). Classification for effective rehabilitation. Rediscovering psychology. Criminal Justice and Behavior, 17(1), 19-52.

Barendregt, C.S. (2015). Needs, Risks, and Protective Factors of Adolescents in Secure Residential Care (diss. Tilburg: Tilburg University).

Berghuis, A.C. \& Waard, J. de (2017). Verdampende jeugdcriminaliteit. Verklaringen van de internationale daling. Justitiële verkenningen, 43(1), 10-27.

Broek, J. van den (2013). Van de straathoek naar Faceboek. Een onderzoek naar het gebruik van social media door jongeren binnen de straatcultuur (masterscriptie Erasmus Universiteit Rotterdam).

Bruinsma, G.J.N. (1991). De test-hertest betrouwbaarheid van de self-report methode. Tijdschrift voor Criminologie, 33(3), 245-255.

Bruinsma, G.J.N. \& Weerman, F.M. (2007). Vernieuwingen in de verklarende jeugdcriminologie. Tijdschrift voor Criminologie, 49(3), 291-305.

CBS (2020a). Rechtsbescherming en veiligheid; historie (1900-2009). Politiestatistiek. Geraadpleegd op www.cbs.nl op 1 juni 2020.

CBS (2020b). Geregistreerde criminaliteit. Registraties van verdachten. Geraadpleegd op www.cbs.nl op 1 juni 2020.

Dijk, J. van, Tseloni, A. \& Farrell, G. (eds.). (2012). The International Crime Drop. New Directions in Research. New York: Springer.

Farrell, G., Tilley, N. \& Tseloni, A. (2014). Why the crime drop? In: M. Tonry (ed.). Crime and Justice, Vol. 43. Chicago: University of Chicago Press, 421-490.

Farrell, G., Tseloni, A., Mailley, J. \& Tilley, N. (2011). The crime drop and the security hypothesis. Journal of Research in Crime and Delinquency, 48(2), 147-175.

Farrington, D.P. \& Welsh, B.C. (2007). Saving Children from a Life of Crime. Oxford: Oxford University Press.

Grinsven, S. van \& Verwest, A. (2017). Vijf jaar Aanpak Top600: waar staan we nu? Justitiele verkenningen, 43(1), 127-141.

Hellemont, E. van (2012). Gangland online: Performing the real imaginary world of gangstas and ghettos in Brussels. European Journal of Crime Crimal Law \& Criminal Justice 20, 165-180.

Heijden, P.G. van der, Sijtsma, K. \& Hart, H. 't (1995). Self-report delinquentie-schalen zijn nog steeds betrouwbaar. Een reactie op de studies van Bruinsma. Tijdschrift voor Criminologie, 37(1), 71-77.

Hoeben, E.M. (2016). Hanging Out and Messing About. Elaborating on the Relationship between Unstructured Socializing and Adolescent Delinquency. Amsterdam: Vrije Universiteit.

Ilan, J. (2020). Digital street culture decoded. Why criminalizing drill music is street illiterate and counterproductive. The British Journal of Criminology. doi:10.1093/bjc/ azz086.

Irwin-Rogers, K. \& Pinkney, C. (2017). Social Media As a Catalyst and Trigger for Youth Violence. London: Catch22. 
Kanne, P., Nannes, L. \& Andringa, W. (2019). Opvoeden. De balans tussen vrijheid geven en verantwoordelijkheid nemen. Amsterdam: I\&O Research.

Kruissink, M. \& Essers, A.A.M. (2004). Zelfgerapporteerde jeugdcriminaliteit in de periode 1990-2001. Den Haag: WODC.

Laan, A.M. van der \& Beerthuizen, M.G.C.J. (2016). Jeugdige zelfgerapporteerde daders. In: A.M. van der Laan \& H. Goudriaan (eds.). Monitor Jeugdcriminaliteit. Ontwikkelingen in de jeugdcriminaliteit 1997 tot 2015. Den Haag: WODC/CBS, 23-50.

Laan, A.M. van der \& Beerthuizen, M.G.C.J. (2018). Monitor Jeugdcriminaliteit 2017. Ontwikkelingen in de jeugdcriminaliteit 1997 tot 2017. Den Haag: WODC/CBS.

Laan, A. van der \& Weijters, G. (2015). Daling in geregistreerde jeugdcriminaliteit. Enkele mogelijke verklaringen. Tijdschrift voor Criminologie, 57(2), 203-228.

Laan, A.M. van der, Beerthuizen, M.G.C.J. \& Goudriaan, H. (2017). Ontwikkelingen in de jeugdcriminaliteit, 1997 tot 2015. Justitiële verkenningen, 43(1), 28-49.

Laan, A.M. van der, Beerthuizen, M.G.C.J. \& Weijters, G. (2016). Jeugdige daders van online-criminaliteit. Cahier Politiestudies, 41(4), 145-168.

Laan, A.M. van der, Rokven, J., Weijters, G. \& Beerthuizen, M.G.C.J. (2018). De daling in jeugddelinquentie: minder risico's, meer bescherming? Tijdschrift voor Criminologie, 60(1), 35.

Laan, P.H. van der, Essers, A.A.M., Huijbregts, G.L.A.M. \& Spaans, E.C. (1998). Ontwikkeling jeugdcriminaliteit: periode 1980-1996; een tussentijds verslag . Den Haag: WODC.

Lipsey, M. \& Cullen, F. (2007). The effectiveness of correctional rehabilitation. A review of systematic reviews. Annual Review of Law and Social Science, 3, 297-320.

McVie, S., Norris, P. \& Pillinger, R. (2020). Increasing inequality in experience of victimization during the crime drop. Analysing patterns of victimization in Scotland from 1993 to 2014-15. The British Journal of Criminology, 60(3), 782-802.

Moffitt, T.E. (2018). Male antisocial behaviour in adolescence and beyond. Nature Human Behaviour, 2(3), 177-186.

OM (2019, 22 november). College van het Openbaar Ministerie stelt jaarstatistieken 2016, 2017 en 2018 van de jeugdparketten voor. Geraadpleegd op www.om-mp.be/sites/ default/files/u1/persconferentie_jstat_jeugd.pdf op 25 augustus 2020.

Osgood, D.W. \& Anderson, A.L. (2004). Unstructured socializing and rates of delinquency. Criminology, 42(3), 519-550.

Patton, D.U., Hong, J.S., Ranney, M., Patel, S., Kelley, C., Eschmann, R. \& Washington, T. (2014). Social media as a vector for youth violence. A review of the literature. Computers in Human Behavior, 35, 548-553.

Pleysier, S., Put, J., Cops, D. \& Op de Beeck, H. (2012). De eeuw van het risicokind? Een criminologische bril in het jeugdonderzoek. In M. De Bie, R. Roose, M. Vandenbroeck (Eds.), Maatschappelijk engagement: een besef van kwetsbaarheid. Liber amicorum Nicole Vettenburg (319-332). Gent: Academia Press.

Politie.nl. (2020, 20 maart). Meer jongeren betrokken bij messteekincidenten. Geraadpleegd op www.politie.nl/nieuws/2020/maart/20/00-meer-jongeren-betrokken-bijmessteekincidenten.html op 8 juli 2020.

Roks, R.A. (2020). Keeping it (hyper)real. A musical history of rap's quest beyond authenticity. In: F. Bovenkerk \& D. Siegel (eds.). Music and Crime. Cham: Springer.

Rokven, J., Weijters, G. \& Laan, A.M. van der (2017). Jeugddelinquentie in de virtuele wereld. Een nieuw type daders of mogelijkheden voor traditionele daders. Den Haag: WODC.

Rovers, B. \& Boers, R. (2009). Vijftig jaar Tijdschrift voor Criminologie in cijfers. Tijdschrift voor Criminologie, 51(2), 116. 
Sleutjes, B. \& Beerthuizen, M.G.C.J. (2018). Hotspots en jeugdige groepsplegers. In: A.M. van der Laan \& M.G.C.J. Beerthuizen (eds.). Monitor Jeugdcriminaliteit 2017. Den Haag: WODC/CBS, 87-96.

Storrod, M.L. \& Densley, J.A. (2017). 'Going viral' and 'going country'. The expressive and instrumental activities of street gangs on social media. Journal of Youth Studies, 20(6), 677-696.

Svensson, R. \& Oberwittler, D. (2019). How can we understand the decline in youth crime? A repeated cross-sectional analysis of self-reported delinquency and explanatory factors, Sweden 1999-2017. Presentatie tijdens de Conference of the European Society of Criminology, Gent.

Swanborn, P.G. (1996). Argumenten en misverstanden rondom de kwaliteit van self-report data. Tijdschrift voor Criminologie, 38(3), 284-289.

Tops, P. \& Tromp, J. (2017, 3 juni). Jongeren geronseld voor prostitutie of drugshandel. Hoe criminele bendes grip hebben op scholen in Nederland. De Volkskrant.

Weerman, F.M. (2017). Social media en smartphones als verklaring voor de daling in jeugdcriminaliteit? Justitiële verkenningen, 43(1), 71-87.

Weerman, F. (2019). Criminaliteit, digitalisering en de online sociale wereld. Dezelfde processen in een nieuwe sociale context? Tijdschrift voor Criminologie, 61(4), 395-404.

Weijers, I., Hepping, K. \& Kampijon, M. (2010). Jeugdige veelplegers. Amsterdam: SWP.

Weijters, G., Laan, A.M. van der \& Kessels, R.J. (2016). De overeenstemming tussen zelfgerapporteerde jeugdcriminaliteit en bij de politie bekende jeugdige verdachten. Den Haag: WODC.

Weijters, G., Verweij, S., Tollenaar, N. \& Hill, J.L. (2019). Recidive onder justitiabelen in Nederland. Verslag over de periode 2006-2018. Den Haag: WODC.

Wennekers, A., Haan, J. de \& Huysmans, F. (2016). Media:Tijd in kaart. Den Haag: SCP. 